\title{
Pengolahan Limbah Kulit Salak Menjadi Kerajinan Dengan Teknik Decaupe Di Dusun Candisari Desa Mranggen
}

\author{
Suswanta1, Anang Setiawan² \\ 1,2 Magister Ilmu Pemerintahan, Program Pascasarjana, Universitas Muhammadiyah Yogyakarta \\ Email: Suswanta@umy.ac.id \\ DOI: $10.18196 / p p m \cdot 31.131$
}

\begin{abstract}
Abstrak
Pemasalahan ekonomi di masyarakat suatu daerah menjadi hal klasik yang memerlukan adanya inovasi-inovasi baru untuk menciptakan lapangan kerja baru yang bisa memberikan pendapatan yang besar kepada masyarakat di sebuah desa. Hal ini pun coba dilakukan di Dusun Candisari yang hamper semua masyarakatnya adalah petani salak. Salak yang telah dipanen hanya akan diberikan kepada pengepul buah salak dan tentu dengan harga jual yang lebih rendah. Dengan melihat kondisi masyarakat dusun yang merupakan petani salak, potensi yang dimiliki itulah yang akan dijadikan sebagai lumbung pendapatan baru. Potensi yang dapat dimaksimalkan adalah dengan memanfaatkan kulit buah salak tersebut menjadi kerjainan dengan harga yang lebih tinggi. Dengan mendatangkan stakeholders yang ahli di bidangnya, masyarakat bisa dilatih cara atau proses pengolahan limbah menjadi kerajinan, pengemasan produk yang menarik, dan sampai pada proses pemasaran produk. Pemanfaatan limbah kulit salak ini diharapkan dapat membuka lapangan kerja baru bagi masyarakat yang tentunya akan meningkatkan taraf hidup masyarakat Dusun Candisari.
\end{abstract}

Kata Kunci: Pengolahan Limbah, Pemasaran Produk, Peningkatan Ekonomi, Dusun Candisari

\section{Pendahuluan}

Desa Mranggen merupakan salah satu desa yang berada di wilayah Kecamatan Srumbung. Desa Mranggen juga memiliki delapan dusun, antara lain Sumbersari, Gondangsari, Rejosari, Pagersari, Candisari, Kalisari, Salamsari, dan Glogosari. Dusun Candisari salah satunya yang menjadi tempat KKN kelompok 092. Dusun Candisari hanya memiliki satu (1) RW, yaitu RW 14 dan dua (2) RT, yaitu RT 01 dan RT 02. Mayoritas masyarakat Dusun Candisari hampir $80 \%$ adalah petani salak, $10 \%$ sebagai peternak kambing Etawa, dan $10 \%$ bekerja sebagai penambang pasir di Merapi.

Potensial Dusun Candisari adalah pertanian. Hal ini membuat masyarakat di sana bermata pencaharian sebagai petani salak. Salak tersebut biasanya langsung di panen dan di jual ke pengepul salak yang berada di salah satu rumah warga Dusun Candisari. Selain itu, warga Dusun Candisari sebagian kecilnya adalah peternak kambing Etawa. Hewan ternak tersebut menghasilkan susu kambing perah. Setiap pagi atau sore dilakukan proses pemerahan. Pada waktu sore atau malam hari, warga Dusun Candisari bekerja sabagai penambang pasir di Merapi.

Dengan banyaknya pohon salak menjadikan Dusun Candisari memiliki potensi lain yang bisa dijadikan tambahan pendapatan bagi masyarakat. Potensi lain yang dimiliki dari salak adalah kulitnya. Kulit salak di beberapa tempat telah dijadikan sebagai bahan kerajinan, baik itu kaya seni maupun hal lain. Hal inilah yang menjadi factor pendorong untuk memanfaatkan potensi yang ada tersebut menjadi sumber pendapatan baru bagi masyarakat sehingga dapat meningkatkan taraf hidup masyarakatnya. Kulit salak bisa dijadikan sebuah karya dengan nilai ekonomi yang tinggi.

Namun, untuk keterampilan masyarakat dalam mengolah kulit salak tersebut masih kurang. Tidak ada orang-orang di Dusun Candisari yang mengetahui cara untuk membuat olahan dari 
kulit salak tersebut. Untuk membantu masyarakat dalam meningkatkan potensi yang dimiliki dusun tersebut, akan dilakukan beberapa pelatihan langsung kepada masyarakat desa sampai pada tahapan pemasaran produknya.

Berdasarkan hasil observasi dan diskusi yang dilakukan dengan pemerintah Desa dan aparatur Pedukuhan Dusun Candisari, prioritas permasalahan mitra adalah sebagai berikut: (1) belum adanya keterampilan dari masyarakat dusun dalam mengolah limbah salak pondoh Dusun Candisari untuk diolah menjadi produk olahan jadi yang dapat diterima oleh masyarakat. (2) belum adanya kemampuan masyarakat untuk melakukan strategi pemasaran produk olahan salak jadi di Dusun Candisari.

Pembangunan yang dimulai dari desa, terutama pada bidang ekonomi, menjadi sebuah keharusan untuk meningkatkan kualitas hidup masyarakat di sebuah desa. Peningkatan ekonomi masyarakat desa dengan menggunakan potensi yang dimiliki desa dapat dilakukan dengan baik apabila mengetahui potensi dan keunggulan yang dimiliki desa tersebut. Model strategi pemberdayaan masyarakat adalah mendukung kinerja agen pembaharu dalam melaksanakan program kegiatan pemberdayaan masyarakat. Oleh karena itu pelaksanaan kegiatan pemberdayaan masyarakat melalui pemanfaatan potensi yang dimiliki suata wilayah sangat penting untuk meningkatkan taraf hidup masyarakat. Keberhasilan program pengembangan UKM untuk meningkatkan pendapatan masyarakat dipengaruhi oleh kondisi dan kearifan lokal (Pattinama, 2009; Sahudiyono, 2009; Yulianto, 2005).

Menurut Jong dan Wenekers (2008), kewirausahaan merupakan pengambilan risiko dengan melihat peluang yang ada untuk menciptakan usaha baru atau pendekatan yang inovatif sehingga menjadikan usaha lebih berkembang besar dan mandiri dalam menghadapi pesaing. Dengan melihat potensi yang ada di Dusun Candisari, Tindakan sangat tepat kiranya untuk melaksanakan program pelatihan pengolahan limbah kulit salak untuk menjadi kerjinan.

\section{Metode Pelaksanaan}

Pembangunan yang dimulai dari desa, terutama pada bidang ekonomi, menjadi sebuah keharusan untuk meningkatkan kualitas hidup masyarakat disebuah desa. Peningkatan ekonomi masyarakat desa dengan menggunakan potensi yang dimiliki desa dapat dilakukan dengan baik apabila mengetahui potensi dan keunggulan yang dimiliki desa tersebut. Model strategi pemberdayaan masyarakat adalah mendukung kinerja agen pembaharu dalam melaksanakan program kegiatan pemberdayaan masyarakat. Oleh karena itu, pelaksanaan kegiatan pemberdayaan masyarakat melalui pemanfaatan potensi yang dimiliki suata wilayah sangat penting untuk meningkatkan taraf hidup masyarakat. Keberhasilan program pengembangan UKM untuk meningkatkan pendapatan masyarakat dipengaruhi oleh kondisi dan kearifan lokal (Pattinama, 2009; Sahudiyono, 2009; Yulianto, 2005).

Menurut Jong dan Wenekers (2008), kewirausahaan merupakan pengambilan risiko dengan melihat peluang yang ada untuk menciptakan usaha baru atau pendekatan yang inovatif sehingga menjadikan usaha lebih berkembang besar dan mandiri dalam menghadapi pesaing. Dengan melihat potensi yang ada di Dusun Candisari, tindakan sangat tepat kiranya untuk melaksanakan program pelatihan pengolahan limbah kulit salak untuk menjadi kerjinan.

Untuk melaksanakan program tersebut, metode yang dilakukan di Dusun Candisari dapat dirumuskan dalam beberapa tahapan sebagai berikut.

1. Observasi awal untuk memetakan permasalahan mitra. Pemataan permasalahan mitra ini dilakukan dengan cara focus group discussion (FGD) dengan tokoh masyarakat, 
kepala dusun, dan aparatur desa setempat. Selain itu, juga dilakukan wawancara secara mendalam dengan Kepala Urusan Perencanaan Desa Mranggen dan beberapa masyarakat untuk mendapatkan informasi yang lebih mendalam terkait permasalahan yang sedang hadapi mitra. Selain pemetaan permasalahan, tim juga memetakan keunggulan dan potensi desa. Informasi-informasi yang telah dikumpulkan dianalisis menggunakan analisis SWOT guna menentukan strategi dan program yang akan dilakukan dalam kegiatan pengabdian dan pemberdayaan desa, khususnya di Dusun Candisari.

2. Kolaborasi dengan stakeholder lain. Kolaborasi dengan stakeholder lain dalam kegiatan pengabdian ini adalah hal yang sangat penting untuk dilakukan. Kolaborasi tersebut dilakukan dalam bentuk kerja sama dalam penyelenggaraan programprogram pengabdian masyarakat khususnya dalam tata kelola administrasi Dusun Candisari. Hal ini diharapkan agar tata kelola kegiatan dan program menjadi efektif, efesien, dan sesuai dengan permasalahan lapangan. Pihak-pihak yang akan dilibatkan secara dominan adalah tim pengusul yang berlatar belakang akademisi, pengusaha sebagai narasumber, mahasiswa KKN, perangkat Dusun Candisari, pemerintah Desa Mranggen, dan masyarakat Dusun Candisari. Selain itu, tim juga melibatkan media sebagai media untuk memublikasi program-program yang telah dilaksanakan.

Adapun peran dari masing-masing stakeholder adalah sebagai berikut.

Tabel 1. Tugas pokok dan fungsi stakeholder

\begin{tabular}{|l|l|}
\hline Stakeholder & Peran \\
\hline Tim Pengusul & $\begin{array}{l}\text { Tim pengusul akan bertindak sebagai coordinator yang mengarahkan jalannya program dan kegiatan } \\
\text { masyarakat. Tim pengusul juga bertindak sebagai fasilitator dan pendampingan dari proses } \\
\text { penyusunan program hingga tahap evaluasi program dan kegiatan pengabdian }\end{array}$ \\
\hline $\begin{array}{l}\text { Pemerintah Desa } \\
\text { Mranggen }\end{array}$ & $\begin{array}{l}\text { Pemerintah desa yang diwakili oleh kepala desa dan perangkat desa juga bertindak sebagai fasilitator } \\
\text { dan penyedia sumber daya pendukung untuk kelancaran program. Pemerintah desa juga bertindak } \\
\text { sebagai mediator antara tim pengusul dan kelompok sasaran. }\end{array}$ \\
\hline Stakeholder terkait & $\begin{array}{l}\text { Sebagai pemberi pelatihan tentang bagaimana proses pembuatan kerajinan, proses pemasaran produk } \\
\text { dan pengemasan produk untuk mudah dipasarkan }\end{array}$ \\
\hline Mahasiswa & $\begin{array}{l}\text { Membantu dan terlibat dalam seluruh proses pelaksanaan kegiatan pengabdian. Mahasiswa juga } \\
\text { terlibat aktif dalam merumuskan konsep program sehingga pada tahap evaluasi program. }\end{array}$ \\
\hline Media Masa & $\begin{array}{l}\text { Dilibatkan untuk meliput dan mempublikasikan kegiatan dan output dari program-program yang telah } \\
\text { dilaksanakan agar dikenal oleh khalayak lainnya. }\end{array}$ \\
\hline
\end{tabular}

1. Pada proses pelaksanaan dilakukan oleh Tim Pengusul dibantu oleh aparatur dusun dan masyarakat setempat. Kegiatan dilaksanakan melalui beberapa kegiatan, di antaranya melakukan sosialisasi kepada masyarakat dengan mengundang stakeholder ahli sebagai pemateri, dan mendampingi masyarakat dalam proses pelatihan pengolahan limbah kulit salak sampai menjadi sebuah produk kerajinan.

2. Program-program yang telah dilaksanakan dalam priode waktu yang telah direncanakan akan dilakukan monitoring secara berkala. Fungsi monitoring program ini adalah untuk mengidentifikasi penyimpangan terkait jalannya program sehingga program dapat berjalan sesuai rencana semula. Selain itu, monitoring program ini dilakukan oleh tim untuk meminimalkan risiko kegagalan dari program-program yang dijalankan. Tim pengusul akan melakukan monitoring setidaknya 2 kali dalam 1 
priode program pengabdian masyarakat tersebut. Selain proses monitoring, juga dilakukan evaluasi program-program yang telah dilakukan. Evaluasi program ini dilakukan untuk menilai capaian akhir dari program- program yang telah dilaksanakan. Pada proses ini, juga akan ditetapkan rencana tindak lanjut untuk tahun-tahun selanjutnya.

\section{Hasil dan Pembahasan}

Pelaksanaan Pengabdian Masyarakat Skema Program Pengembangan Desa Mitra (PPDM) di Dusun Candisari Desa Mranggen, Srumbung, Magelang, Jawa Tengah berjalan dengan baik. Program ini berupa pelatihan pengolahan limbah kulit salak menjadi kerajinan dengan teknik decaupe. Hal ini dipicu dengan rendahnya kesadaran 3R, yaitu reuse (memakai kembali barang bekas yang masih bisa dipakai), reduce (berusaha mengurangi sampah), dan recycle (mendaur ulang sampah agar dapat dimanfaatkan). Kondisi ini menjadi pertimbangan untuk mencari cara yang tepat dalam memanfaatkan limbah kulit salak yang cukup banyak di Desa Mranggen agar mampu memberikan keuntungan nyata bagi masyarakat (produktif).

Keterbatasan pengetahuan warga Desa Mranggen akan kebermanfaatan salak. Tidak sedikit masyarakat yang menganggap bahwa salak sebagai buah saja dan membuang kulitnya ke tempat sampah. Padahal, buah salak dapat dibuat menjadi brownies. Hal ini dapat menaikan harga salak jika telah diolah menjadi brownies. Masyarakat Mranggen sangat antusias dalam mengikuti pelatihan ini. Pelatihan ini mengundang trainer yang berkompeten, yakni Ibu Ari Erta Kumala H., S.S., selaku owner dari Omah Salak di Turi, dan Ibu Liya Budi H. Dalam sambutannya, Dr. Suswanta, M.Si. mengatakan pelatihan pembuatan brownies ini, selain memberikan keterampilan baru bagi para ibu di Desa Mranggen, juga bertujuan untuk meningkatkan ekonomi keluarga sehingga kelak sesudah kegiatan pelatihan ini diharapkan mereka bisa brownies sendiri dan dijadikan salah satu sumber pendapatan keluarga untuk menopang kemandirian ekonomi keluarga.

\section{Gambar 1.1. Kue Brownis Salak}

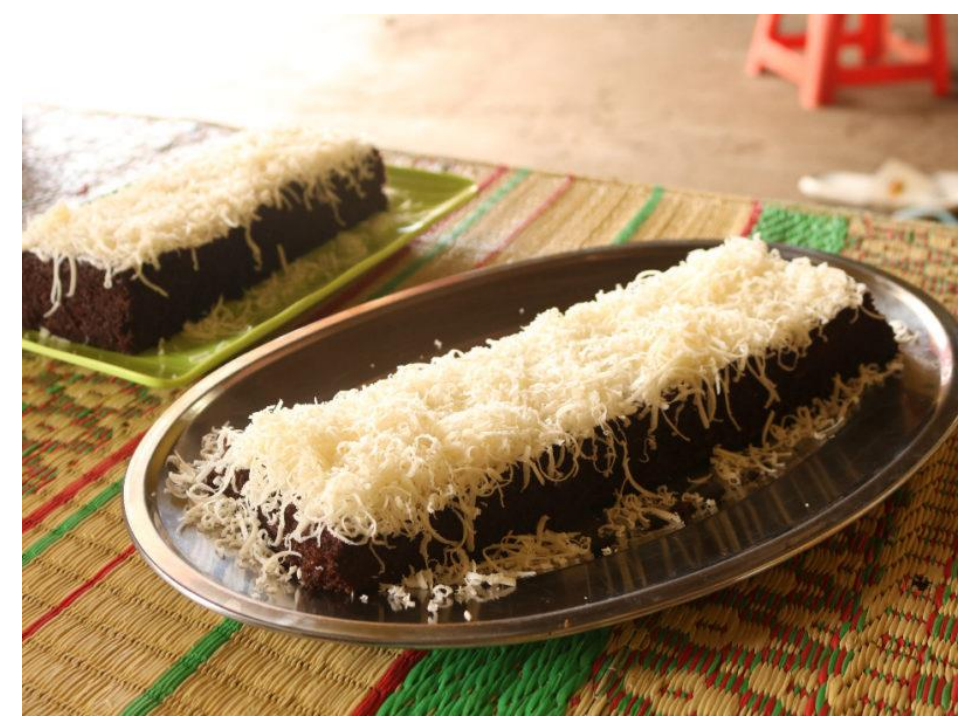

Proses pembuatannya tidak rumit. Pertama, memotong buah salak menjadi kecil-kecil. Selanjutnya, cokelat batangan dicairkan sampai teksturnya menjadi cair. Setelah coklat 
mencair, kemudian ditambahkan minyak sayur. Setelah itu, membuat bahan kering, yaitu mencampurkan tepung terigu, coklat bubuk, dan baking powder. Langkah selanjutnya adalah membuat adonan basah dengan mencampurkan telur, gula pasir, vanili, dan ovalet. Kemudian adonan basah dikocok sampai mengembang. Setelah adonan mengembang, hal yang dilakukan adalah mencampurkan adonan kering dengan adonan basah. Lalu ditambahkan coklat cair dan diaduk sampai rata. Selanjutnya, ditambahkan buah salak yang sudah dipotong kecil-kecil. Selanjutnya, mengolesi loyang dengan margarin. Setelah itu, menuangkan adonan ke dalam loyang dan loyang siap untuk dikukus.

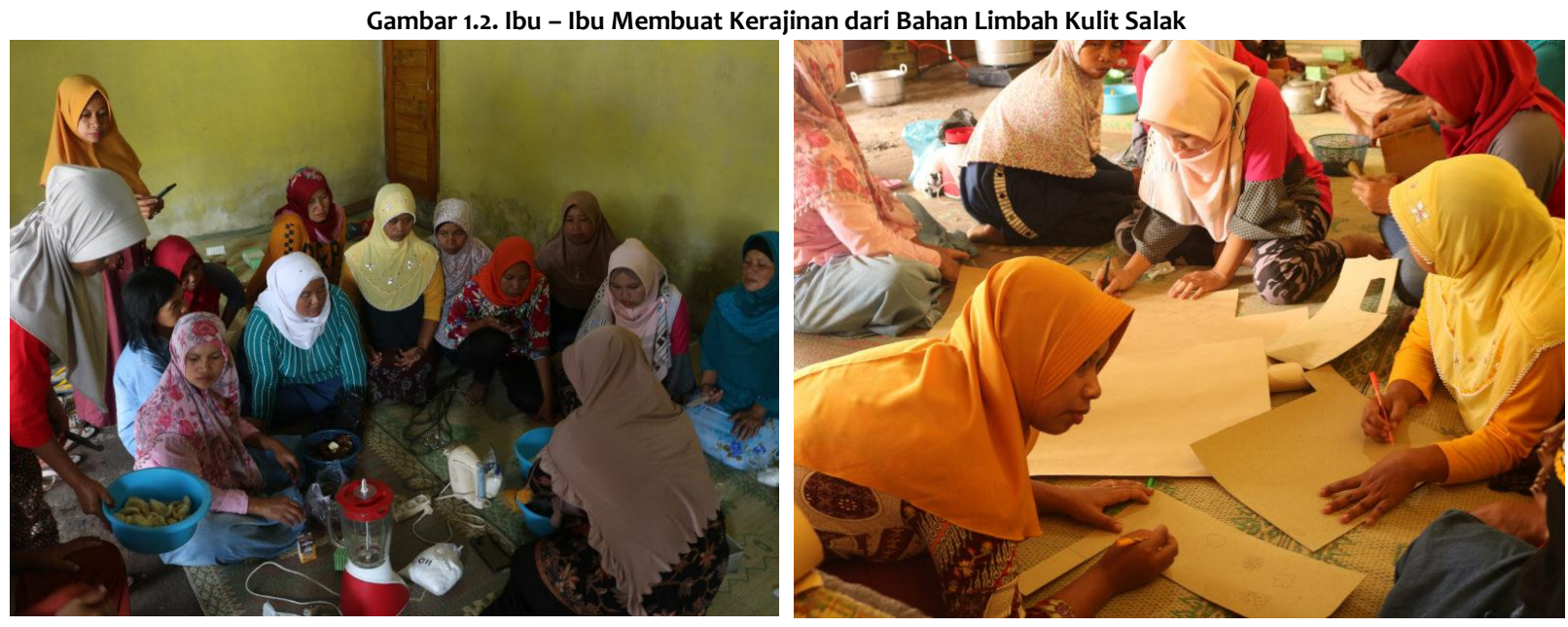

Gambar 1.3. Kotak Tisu, Bingkai Foto dan Gantungan Kunci Bahan Limbah Kulit Salak

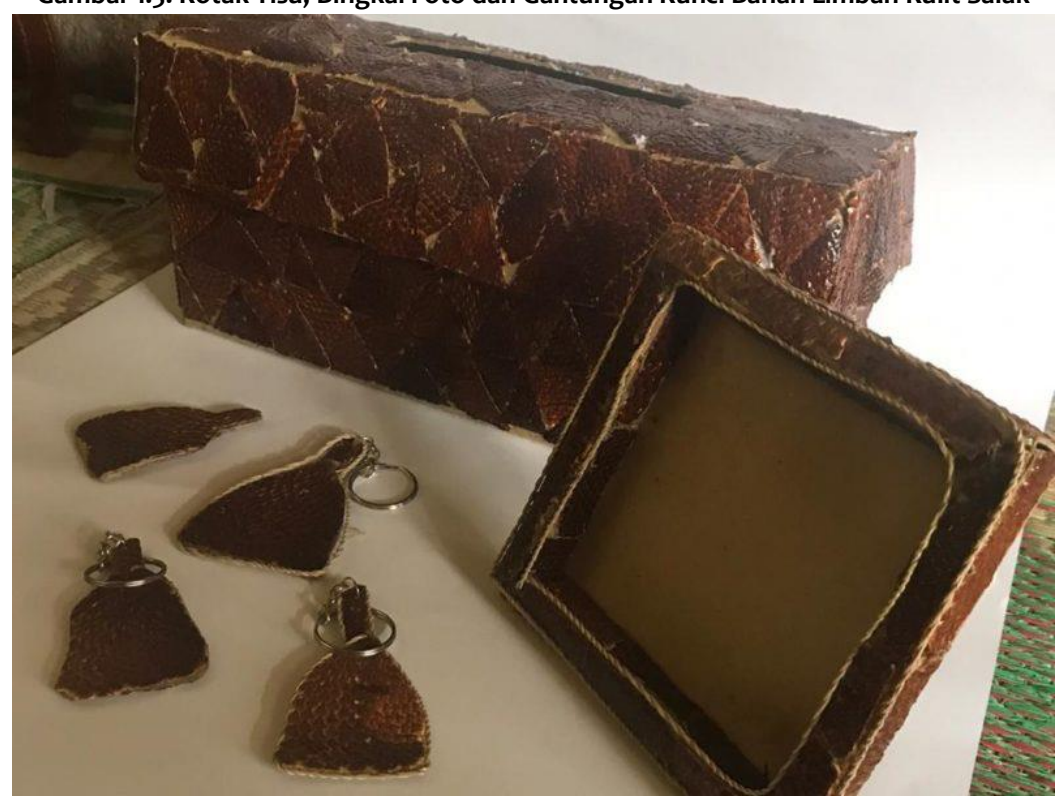

"Pelatihan pembuatan brownis ini sangat bermanfaat sekali bagi kami yang bermukim di desa. Karena dengan kegiatan ini, kami akhirnya bisa tahu cara membuat brownis yang enak dan murah," ujar Partinah, salah satu satu warga yang mengikuti kegiatan tersebut. Selain membuat brownis, masyarakat juga diajarkan cara mengolah kulit salak agar menciptakan ekonomi baru di desa tersebut. Kerajinan ini sangat membantu jika ada wisatawan yang datang ke desa tersebut. Hal ini menjadi tanda pengingat masyarakat kepada desa tersebut. Ibu - ibu Desa Mranggen membuat gantungan kunci, pin dan kotak tisu dengan bahan dasar kulit 
salak. Masyarakat tampak antusias dengan program ini karena bisa menjadi keterampilan bagi ibu - ibu Desa Mranggen dalam pemanfaatan limbah.

Hasil kegiatan Pengabdian Masyarakat Skema Program Pengembangan Desa Mitra (PPDM) secara garis besar dapat dilihat berdasarkan beberapa komponen berikut.

1. Keberhasilan target jumlah peserta pelatihan

Keberhasilan target jumlah peserta pelatihan dapat dikatakan sangat baik, mengingat target jumlah peserta pelatihan sebanyak 30 orang dan dalam pelaksanaan kegiatan dapat hadir sebanyak 30 orang (100\%). Hal ini didukung peran Ibu Kepala Dusun, mulai dari persiapan, penyebaran undangan, pengadaan konsumsi, tempat, dan peralatannya.

2. Ketercapaian tujuan pelatihan

Ketercapaian tujuan pelatihan dapat dikatakan baik (80\%). Hal ini disebabkan adanya peningkatan pengetahuan dari peserta, setidaknya dari yang dulunya tidak tahu menjadi tahu. Kegiatan pengabdian ini berhasil memberdayakan perempuan di Desa Mranggen untuk mengolah limbah kulit salak menjadi bahan kerajinan yang bernilai ekonomis.

3. Ketercapaian target materi yang telah direncanakan

Ketercapaian target materi yang telah direncanakan pada kegiatan PPDM ini dapat dikatakan baik $(80 \%)$ karena materi pelatihan dapat disampaikan secara keseluruhan meskipun tidak secara detail karena keterbatasan waktu. Materi pelatihan yang telah disampaikan adalah konsep pembuatan kerajinan dari bahan limbah kulit salak dan promosi kerjinan.

\section{Kemampuan peserta dalam penguasaan materi}

Kemampuan peserta dalam penguasaan materi dapat dikatakan cukup (80\%). Hal ini disebabkan waktu yang terbatas dalam penyampaian materi dengan menggunakan metode ceramah dan demonstrasi serta didukung kemampuan para peserta yang berbeda dalam menyerap materi yang disampaikan

\section{Simpulan}

Berdasarkan uraian dalam pembahasan, kegiatan pengabdian masyarakat di Desa Mranggen dapat disimpulkan sebagai berikut:

1. Pelatihan pengolahan limbah kulit salak menjadi kerajinan dengan teknik decaupe di lokasi pengabdian dapat meningkatkan pengetahuan perempuan, setidaknya dari tidak tahu menjadi tahu. Kegiatan ini berhasil memberdayakan perempuan untuk memanfaatkan limbah kulit salak menjadi kerajinan.

2. Peningkatan pemahaman bagi peserta pelatihan dilakukan dengan metode ceramah dan demonstrasi serta pemberian kesempatan untuk tanya jawab.

\section{Ucapan Terima Kasih}

Penulis mengucapkan terima kasih kepada Lembaga Penelitan, Publikasi dan Pengabdian Masyarakat Universitas Muhammadiyah Yogyakarta yang telah memberikan izin dan memberikan pendanaan sehingga kegiatan ini dapat berjalan secara lancar. Penulis juga mengucapkan terima kasih kepada segenap mitra yang telah mendukung berjalannya kegiatan ini, yaitu masyarakat Desa Mranggen dan pemerintah Desa Mranggen. 


\section{Daftar Pustaka}

Cipta Nugraha, P. G. S. (2020). Sebuah Review Perancangan Website Sebagai Media Pemasaran Dan Penjualan Industry XYZ Florist. Jurnal Ilmiah Vastuwidya, 2(1), 65-71. https://doi.org/10.47532/jiv.v2i1.76

Hairunisya, N., Subiyantoro, H., \& Kartadie, R. (2019). PKM Pendampingan Sadar Wisata dan Pengembangan Website Desa. MATAPPA: Jurnal Pengabdian Kepada Masyarakat, 2(2), 91. https://doi.org/10.31100/matappa.v2i2.442

Hamzah, H., Adnan, Y. M., Daud, M. N., Alias, A., \& Dali, M. M. (2015). A SMART CITY ASSESSMENT FRAMEWORK. Jurnal Teknologi, 1, 1-5.

Hidayah, A., \& Warjiyono. (2015). Pembangunan Website Desa Kalisoka Guna Meningkatkan Daya Saing Pariwisata Kabupaten Tegal. Jurnal Evolusi, 3(2), 10.

Kuryanti, S. J., \& Indriani, N. (2018). Pembuatan Website Sebagai Sarana Promosi Pariwisata. Jurnal \& Penelitian Teknik Informatika, 2(2), 37-46. Retrieved from https://jurnal.polgan.ac.id/index.php/sinkron/article/download/116/64/

Maita, I., Marni, Suryani, D., \& Agustin, W. (2018). Analisis Perbandingan Website ecommerce. Seminar Nasional Teknologi Informasi, Komunikasi Dan Industri (SNTIKI10), (11), 165-170.

Puad, L. (2017). Pemanfaatan Google Maps API Dalam Pemetaan Desa Wisata Di Indonesia Berbasis Website. Jurnal Akademika, 60-63. Retrieved from http://ojs.stmiknh.ac.id/index.php/akademika/article/view/244

Slamet Riyanto, \& Kurniawati, I. D. (2018). Rancang Bangun Website Desa Kresek-Madiun Untuk Media Informasi Potensi Wisata Alam Dan Kulinier. JUSIKOM PRIMA (Junal Sistem Informasi Ilmu Komputer Prima), 26(2), 4549-4556.

Umira Dewi, M. H., Fandeli, C., \& Baiquni, M. (2013). Pengembangan Desa Wisata Berbasis Partisipasi Masyarakat Lokal Di Desa Wisata Jatiluwih Tabanan, Bali. Jurnal Kawistara, 3(2), 129-139. https://doi.org/10.22146/kawistara.3976

Widiartha, I. M., \& Muliantara, A. (2017). Pelatihan Pembuatan Website Desa Sebagai Pusat Informasi. 16(September), 316-325.

Yunita, N. P. (2018). Kondisi Terkini Perkembangan e-Government di Indonesia : Praktik Pemerintah dan Persepsi Publik. 1-87. Retrieved from https://dspace.uii.ac.id/handle/123456789/12677

nilai-nilai Pancasila 